\title{
Exploring Factors Affecting Consumers' Adoption of Shopping via Mobile Applications in Turkey
}

\author{
Oğuz YILDIZ ${ }^{1} \&$ Hakan KİTAPÇI ${ }^{2}$ \\ ${ }^{1}$ Institute of Social Science, Gebze Technical University, Gebze, Kocaeli, Turkey \\ ${ }^{2}$ Faculty of Business Administration, Gebze Technical University, Gebze, Kocaeli, Turkey \\ Correspondence: Oğuz YILDIZ, Institute of Social Science, Gebze Technical University, Gebze, Kocaeli, \\ Turkey.
}

Received: March 1, 2018 Accepted: March 20, 2018 Online Published: May 7, 2018

doi:10.5539/ijms.v10n2p60 URL: https://doi.org/10.5539/ijms.v10n2p60

\begin{abstract}
The aim of this study is to identify the factors behind consumers' adoption of shopping via mobile applications and to develop a new model that explains this situation. The related literature was examined for this purpose. Delphi technique was preferred to determine factors in the study. Data was collected through questionnaires. Exploratory Factor Analysis (EFA) was conducted with SPSS. A research model based on an integration of various theoretical fields was developed. As a result of EFA, ten new dimensions emerged in the study. And then, in order to statistically analyze the measurement and structural models, this study used Smart PLS for Structural Equation Modeling (SEM) technique. After path analysis with Smart PLS, a new conceptual model was developed to explain adoption of shopping via mobile applications by consumers in Turkey. Structures such as Personalization, Word of Mouth Communication and Perceived Mobility used in the model developed within the scope of this research, but rarely used in this field of studies, were verified to be determinants of shopping behavior via mobile applications in Turkey. The model developed within the study is both valid and reliable in terms of its structure and all relations established within the scope of the model are significant.
\end{abstract}

Keywords: consumer adoption, exploratory factor analysis, mobile applications, mobile shopping, structural equation modeling, smart PLS

\section{Introduction}

According to the data obtained from the Information and Communication Technologies Authority (ICTA), together with the transition to $4.5 \mathrm{G}$ technology in April 2016, the number of $3 \mathrm{G}$ subscribers decreased to 15 million while the number of $4.5 \mathrm{G}$ subscribers reached to 56 million by the end of March 2017. Again by March 2017 in Turkey, the number of mobile broadband subscriptions getting internet services through both mobile computers and mobile devices were about 53 million (ICTA Market Data, 2017). In addition, according to data of ICTA, numbers of mobile broadband internet subscriptions were 12.5 million in Istanbul, 2016 (ICTA Yearly Provincial Statistics, 2017). According to another data of statistics, the number of smart phone users in Turkey is about 28 million and it is expected to reach 40 million by 2018 (eMarketer, 2014).

When the "Turkey Advanced Payments Report" published by the Interbank Card Center (BKM) in 2016 is analyzed, it is understood that the share of online payments within total numbers equals to 68 billion TRY (total amount is 587 billion TRY); the share of mobile payments within all retail online payments increased from \%20 to $\% 30$ in Turkey, 2016 (BKM, 2016). The abovementioned number of mobile broadband subscriptions and data about mobile marketing activities indicate that mobile shopping is developing as a booming market in Turkey.

According to the Mobile Marketing Association, mobile marketing is defined as "a set of practices that enables organizations to communicate and engage with their audience in an interactive and relevant manner through any mobile device or network" (MMA, 2009). Downloadable applications, on the other hand, are defined as "programs designed specifically to add functionality to mobile handsets and are able to interact directly with the technical features of the phone" (Chiem et al., 2010). According to another definition, these applications are designed for operating systems of mobile devices and as end-user software that may increase capacity of devices (Purcell, 2011).

The purpose of this study is to identify the factors behind consumers' adoption of shopping via mobile 
applications and to develop a new conceptual model that explains this situation. For this purpose, the literature review of this study was conducted on reviews about mobile technologies (Leppäniemi, Sinisalo, \& Karjaluoto, 2006; Ngai \& Gunasekaran, 2007; Varnali \& Toker, 2010; Zhang, Zhu, \& Liu, 2012; Ström, Vendel, \& Bredican, 2014). The literature review covers articles about theories and models used to analyses acceptance and adoption of new technologies as well as those about acceptance and adoption of mobile marketing applications, mobile advertisements, mobile commerce, mobile banking, mobile shopping and mobile services by consumers. The literature review within the scope of this study identified a good number of factors that affect consumers' adoption of shopping via mobile applications and these factors were evaluated and eliminated by ten marketing experts using the Delphi Technique. After the evaluating process, some conceptual structures were subjected to an EFA. The dimensions obtained as a result of the EFA were included in the research model which is an integration of various theoretical fields. In order to statistically analyze the measurement and structural models, this study used Smart PLS for Structural Equation Modeling (SEM) technique.

Following section starts with a literature review which examines basic theories and models, and proceeds with the explanation of factors affecting consumer adoption in mobile marketing literature. After the literature section, the present study explains research design and methodology, and continues with results of the study, discussion of results and conclusions. The study ends with limitations and future research.

\section{Literature Review and Conceptual Framework}

There is a wide body of literature that studies consumers' attitudes and intentions toward as well as acceptance and adoption of mobile marketing activities (Bauer, Reichardt, Barnes, \& Neumann, 2005; Barutçu, 2007; Barutçu, 2008; Sultan, Rohm, \& Gao., 2008; Gao, Sultan, \& Rohm, 2010; Uygun, Divanoğlu, \& Özçif̧̧i, 2012; Yüce, Deniz, \& Gödekmerdan, 2012; Rui-jin, \& Xiang-yang, 2012; Yousif, 2012; Gao, Rohm, Sultan, \& Huang, 2012; Gao, Rohm, Sultan, \& Pagani, 2013; Al-Meshal \& Almotairi, 2013; Ryu \& Murdock, 2013; Chinomona \& Sandada, 2013). It was often observed that researchers developed a model by synthesizing research related structures and various basic models in studies such as Theory of Reasoned Action, Technology Acceptance Model, Theory of Planned Behavior, Innovation and Diffusion Theory, Uses and Gratification Theory etc. On the other hand, a significant number of studies about acceptance and adoption of mobile commerce and mobile shopping by consumers were identified within the literature (Yang, 2005; Wu \& Wang, 2005; Mahatanankoon, Wen, \& Lim, 2005; Bigné, Ruiz, \& Sanz, 2007; Bhatti, 2007; Wei, Marthandan, Chong, Ooi, \& Arumugam, 2009; Khalifa \& Shen, 2008; Chong, Chan, \& Ooi, 2012; Jarvenpaa, Lang, Takeda, \& Tuunainen, 2003; Aldas-Manzano, Ruiz-Mafe, \& Sanz-Blas, 2009; Lu \& Su, 2009; Yang, 2010; Chiem et al., 2010; Yang, 2012; Yang \& Forney, 2013; Yang, 2013; Kumar \& Mukherjee, 2013; Uğur \& Türkmen, 2014; Assaurt \& Eiamkanchanalai, 2015; Wang, Malthouse, \& Krishnamurthi, 2015; Agrebi \& Jallais, 2015).

\subsection{Basic Theories and Models}

\subsubsection{Theory of Reasoned Action}

The theory (Ajzen \& Fishbein, 1980) considers "intention" as a determining factor for the decision to display a specific behavior or not. According to this theory, intention is a function of two determining factors, nature of the person and social influence. The personal factor consists of positive or negative individual evaluations taken as reference when performing the behavior. The term used to describe this situation is "attitude toward the behavior". The second determinant of intention is an individual's perception of the social behavior put on him or her to perform or not to perform the behavior in question and this factor is termed as "subjective norm". The theory claims that behavior is determined by behavioral intention, while behavioral intention is a function of individual attitude toward the behavior and a function of social norms (Ajzen \& Fishbein, 1975). In the study, marketing experts reached on a consensus about that subjective norm has an impact on the consumers' adoption of shopping via mobile applications.

\subsubsection{Technology Acceptance Model}

This model aims to identify external factors that affect intrinsic beliefs, attitudes and intentions. In order to achieve this aim, the model theoretically bases on the model of reasoned action. In a way similar to Theory of Reasoned Action, Technology Acceptance Model suggests that use of computers is determined by behavioral intentions while behavioral intentions are determined by individuals' attitude toward use of systems and the perceived usefulness (Davis, Bagozzi, \& Warshaw, 1989). The theory focuses on "perceived usefulness" and "perceived ease of use" concepts and in this way aims to identify the fundamental factors behind use of systems.

A number of scholars in the field suggest that additional factors are needed to enhance this model. Therefore an extended version of the technology acceptance model, called as TAM 2, was developed. Within the scope of this 
model, the social influence process which consists of subjective norm, voluntariness and image components and the cognitive instrumental process consisting of job relevance, output quality, result demonstrability and perceived ease of use significantly affect user's acceptance (Venkatesh \& Davis, 2000). In the study, marketing experts reached on a consensus about that image has an impact on the consumers' adoption of shopping via mobile applications. The image is described as the perception that use of an innovation increases one's status within the social system (Moore \& Benbasat, 1991).

Another study within the field developed an integrated model at the user level (TAM 3), based on the suggestion that there is a lack of research on the role of interventions in information technologies which are considered helpful for managerial decision making mechanisms. The study also suggests new concepts as determinants of the perceived usefulness and the perceived ease of use concepts, namely individual differences, system characteristics, social influence and facilitating conditions. In the study, marketing experts reached on a consensus about that facilitating conditions have an impact on the consumers' adoption of shopping via mobile applications. Facilitating conditions refer to organizational support which makes use of information technologies possible (Venkatesh \& Bala, 2008).

According to the model (TAM3), determinants of the perceived usefulness are the perceived ease of use, subjective norms, image, job relevance, output quality and result demonstrability concepts. In addition, determinants of the perceived ease of use concept mentioned by the model include computer self-efficacy, perception of external control, computer anxiety, computer playfulness, perceived enjoyment, and objective usability. In the study, marketing experts reached on a consensus about that perceived enjoyment has an impact on the consumers' adoption of shopping via mobile applications. Perceived enjoyment refers the degree to which an activity of using a system is perceived to be enjoyable (Venkatesh, 2000).

\subsubsection{Theory of Planned Behavior}

Theory extends Theory of Reasoned Action by taking perceived behavioral control in consideration, which refers to users' perception about internal and external restrictions that may affect the behavior (Ajzen, 1991). Perceived behavioral control means availability of opportunities, sources and purposes (time, money, skills, cooperation with others) for an individual to enable him or her to display a specific behavior and to ensure success of this behavior (Ajzen, 1991). In the study, marketing experts reached on a consensus about that perceived behavioral control has an impact on the consumers' adoption of shopping via mobile applications.

\subsubsection{Innovation and Diffusion Theory}

The theory explains the main component in terms of diffusion of new ideas and thoughts as; diffusion of (1) an innovation (2) through communication using certain channels, (3) in a specific time and (4) among members of the social system (Rogers, 1995). According to this theory, the degree to which members of the social system perceive characteristics of an innovation determines the rate of adoption. An innovation has five characteristics: (1) Relative advantage, (2) compatibility, (3) complexity, (4) trialability and (5) observability (Rogers, 1995). First three of these factors were identified as in relation with the decision to adopt (Tornatzky \& Klein, 1982) and use of information technologies (Moore \& Benbasat, 1993).

Relative advantage indicates the degree to which the innovation is more useful than the replaced situation (Roger, 1995). The benefits in this regard consist of economic benefits, image development, ease of use and satisfaction. These benefits share similarities with the usefulness factor included in the TAM (Taylor \& Todd, 1995). Complexity refers to the level of difficulty in learning, understanding and applying an innovation (Rogers \& Shoemaker, 1971). This concept shows similarity with the ease of use component of the TAM (Taylor \& Todd, 1995). Compatibility, on the other hand, explains the degree to which the innovation complies with values, previous experience and current needs of the adopter (Roger, 1995). In the study, marketing experts reached on a consensus about that compatibility has an impact on the consumers' adoption of shopping via mobile applications.

\subsubsection{Technology Readiness Index}

Technology Readiness Index was developed by Parasuraman in 2000. The aim of this index is to identify preventive and encouraging factors in terms of individuals' tendency to use new technologies. The Technology Readiness Index consists of four dimensions. These four dimensions are optimism, which refers to a positive approach toward technologies; innovativeness, which indicates the tendency to be a leader in a specific technology and thought; discomfort, which is perceived lack of control over technology; and finally insecurity, distrust of technology and skepticism about its ability to work properly (Parasuraman, 2000).

In the study, marketing experts reached on a consensus about that innovativeness has an impact on the 
consumers' adoption of shopping via mobile applications.

\subsection{Mobile Marketing Literature Review}

The literature review conducted within the scope of this study was based on reviews about mobile technologies (Leppäniemi, Sinisalo, \& Karjaluoto, 2006; Ngai \& Gunasekaran, 2007; Varnali \& Toker, 2010; Zhang, Zhu, \& Liu, 2012, Ström, Vendel, \& Bredican, 2014). Within this context, articles that are analysed by the studies in question were scanned in line with the aims of this study. It was identified that studies within the literature analysis consumers' acceptance and adoption of mobile marketing activities (Bauer, Reichardt, Barnes, \& Neumann, 2005; Barutçu, 2007; Barutçu, 2008; Sultan, Rohm, \& Gao., 2008; Gao, Sultan, \& Rohm, 2010; Uygun, Divanoğlu, \& Özçifçi, 2012; Yüce, Deniz, \& Gödekmerdan, 2012; Ruijin, \& Xiangyang, 2012; Yousif, 2012; Gao, Rohm, Sultan, \& Huang, 2012; Gao, Rohm, Sultan, \& Pagani, 2013; AlMeshal \& Almotairi, 2013; Ryu \& Murdock, 2013; Chinomona \& Sandada, 2013), mobile advertisements (Leppäniemi \& Karjaluoto, 2005; Xu, 2006; Vatanparast \& Asil, 2007; Merisavo et al., 2007; Okazaki, 2007; Barutçu \& Göl, 2009; Usta, 2009; Şahin \& Aytekin, 2012; Özgüven, 2013), mobile services (Nysveen, Pedersen, \& Thorbjørnsen, 2005; James, Thong, Moon, \& Tam, 2008; Turel, Serenko, \& Bontis, 2007; Lu, Liu, Yu, \& Wang, 2008; Pagani, 2004; Kleijnen, Ruyter, \& Wetzels, 2004; Hung \& Chang, 2005; Luarn \& Lin, 2005; Park \& Yang, 2006; Kim, Chan, \& Gupta, 2007; Rao \& Troshani, 2007; Lopez-Nicolas, Molina-Castillo, \& Bouwman, 2008; Kim \& Han, 2009; Faziharudean \& Li-Ly, 2011; Kim, 2012; Du, Zhu, Zhao, \& Lv, 2012; Zarmpou, Saprikis, Markos, \& Vlachopoulou, 2012; Wang \& Lin, 2012), mobile commerce (Yang, 2005; Wu \& Wang, 2005; Mahatanankoon, Wen, \& Lim, 2005; Bigné, Ruiz, \& Sanz, 2007; Bhatti, 2007; Wei, Marthandan, Chong, Ooi, \& Arumugam, 2009; Khalifa \& Shen, 2008; Chong, Chan, \& Ooi, 2012; Jarvenpaa, Lang, Takeda, \& Tuunainen, 2003) and mobile shopping (Aldas-Manzano, Ruiz-Mafe, \& Sanz-Blas, 2009; Lu \& Su, 2009; Yang, 2010; Chiem et al., 2010; Yang, 2012; Yang \& Forney, 2013; Yang, 2013; Kumar \& Mukherjee, 2013; Uğur \& Türkmen, 2014; Assaurt \& Eiamkanchanalai, 2015; Wang, Malthouse, \& Krishnamurthi, 2015; Agrebi \& Jallais, 2015) and attempt to determine the factors which have influence on consumers' attitude and behavioral intention.

This section of the study covers original structures which are not mentioned in aforementioned models but encountered within the literature. It is observed that the Value Based Adoption Model, which explains consumers' adoption of mobile internet in terms of value maximization, uses the concept of the perceived value (Kim, Chan, $\&$ Gupta, 2007). Within the scope of this model, the perceived value refers to the exchange between advantages obtained by the consumers such as relevant features and benefits and the resources used such as price, opportunity cost, time and necessary effort. Therefore the concept covers the perceived monetary value and the perceived cost as well (Zhang, Zhu, \& Liu, 2012; Wei, Marthandan, Chong, Ooi, \& Arumugam, 2009; Faziharudean \& Li-Ly, 2011; Kim, 2012). The level of preexisting knowledge about the innovation itself or a similar product/service, or existing knowledge, reduces the innovation's degree of complexity (Bauer, Reichardt, Barnes, \& Neumann, 2005; Yang, 2005). Perceived mobility refers to the fact that mobile services enable widespread and instant communication. "Positive Word of Mouth Communication" focuses on individuals' willingness to recommend products and services and encourage use of them as a result of loyalty, rather than their own future use and purchasing behavior (Assarut \& Eiamkanchanalai, 2015; Turel, Serenko, \& Bontis, 2010). Perceived Informativeness refers to his or her perceiving products and services of mobile applications as a significant source of knowledge (Bauer, Reichardt, Barnes, \& Neumann, 2005; Okazaki, 2007). Perceived risk consists of three key concepts (Lu, Liu, Yu, \& Wang, 2008). These are protection during the data transmission process and of data storages, privacy concerns, success in achieving desired outcomes. In conclusion, personalization refers to the customized offerings related to products and services sent by a mobile application (Xu, 2006).

Marketing experts reached on a consensus about seven structures mentioned above in this section. On the other hand, structures like need for uniqueness, mobile affinity, media effect, trialability were excluded from the study.

\section{Research Design and Methodology}

The literature review within the scope of this study identified a good number of factors that affect consumers' adoption of shopping via mobile applications and these factors were analyzed by ten marketing experts using the Delphi Technique. As a result of mentioned technique, certain conceptual structures that are Perceived Usefulness (PU), Perceived Ease of Use (PEOU), Perceived Behavioral Control (PBC), Subjective Norms (SN), Image (IMA), Perceived Entertainment (PE), Facilitating Conditions (FC), Innovativeness (INN), Compatibility (COMP), Existing Knowledge (EN); Perceived Value (PV), Perceived Mobility (PM), Word of Mouth Communication (WOM), Perceived Informativeness (PI), Perceived Risk (PR) and Personalization (PER) were included in the study to be subjected to an EFA. The items in table-1 were adapted from the studies on mobile 
technologies reviewed within the literature and modified to be compatible with the study. The present study includes: four items measuring Perceived Usefulness (Davis, Bagozzi, \& Warshaw, 1989; Ahn, Ryu, \& Han, 2004; Wu \& Wang, 2005); five items measuring Perceived Ease of Use (Davis, Bagozzi, \& Warshaw, 1989; Nysveen, Pedersen, \& Thorbjørnsen, 2005); four items measuring Perceived Value (Sirdeshmukh, Singh, \& Sabol, 2002; Kim, Chan, \& Gupta, 2007); four items measuring Perceived Risk (Bauer, Reichardt, Barnes, \& Neumann, 2005; Wu \& Wang, 2005); four items measuring Perceived Enjoyment (Nysveen, Pedersen, \& Thorbjørnsen, 2005); five items measuring Innovativeness (Goldsmith \& Hofacker, 1991; Parasuraman, 2000); three items measuring Existing Knowledge (Flynn \& Goldsmith, 1999; Bauer, Reichardt, Barnes, \& Neumann, 2005); four items measuring Word of Mouth Communication (Lin, Sher, \& Shih, 2005; Turel, Serenko, \& Bontis, 2010); three items measuring Perceived Mobility (Hong, Thong, Moon, \& Tam, 2008); three items measuring Personalization (Mittal \& Walfried, 1996; Chellappa \& Sin, 2005; Xu, 2006); three items measuring Perceived Informativeness (Bauer, Reichardt, Barnes, \& Neumann, 2005); two items measuring Subjective Norm (Bhattacherjee, 2000; Nysveen, Pedersen, \& Thorbjørnsen, 2005); two items measuring Image (Moore \& Benbasat, 1991). Moreover, Attitude and Behavioral Intention concepts mentioned in the final model of the study were measured with three items for each (Shimp \& Kavas, 1984; Bauer, Reichardt, Barnes, \& Neumann, 2005; Yang \& Zhou, 2011). In conclusion, the conceptual structure of Behavior was examined by addressing two questions (Kim, 2012). In order to efficiently identify the factors behind consumers' adoption of shopping via mobile applications, the sample of this study was chosen from people who do shopping via mobile applications. It means that the study uses a nonrandom method which is called as the judgmental sampling. The data was collected through questionnaires conducted between April-June, 2017, from 450 consumers who live in Istanbul, Turkey and use mobile applications for shopping but only 438 of them were included in the analysis process. 64 variables to be analyzed were scaled by a 5point Likert type scale and the respondents were asked to answer these questions by choosing points from (1) strongly disagree to (5) strongly agree.

An EFA with SPSS was conducted in order to identify dimensions of the data collected from consumers. The dimensions obtained as a result of the EFA were included in the research model and the relations within the literature (Figure 1) Contrary to covariance based AMOS and LISREL path modeling techniques (CB-SEM), SMART PLS is a regression based technique which rests upon the path analysis (Chinomona \& Sandada, 2013). A study conducted with SMART PLS and AMOS to explore the structural equation modeling compatible with confirmatory factor analysis revealed that values of PLS-SEM are more efficient than those of CBSEM, even when the data is same (Afthanorhan \& Afthanorhan, 2013). Smart PLS software has sufficient capacity to process complicated prediction models on small and medium scaled samples. After EFA, due to the reasons mentioned above, this study used Smart PLS software in order to statistically analyze the measurement and structural models.

\section{Results}

When the data associated with participants are examined (Table 2), it is seen that $64 \%$ of those using mobile applications for shopping are in $26-36$ age group, $42 \%$ are female and $58 \%$ were male, while $80 \%$ of all participants have a monthly income over the value of minimum wage applied in Turkey.

Data of the 438 participants were subjected to an EFA with SPSS software, within the framework of the study. It is often mentioned as a general rule that factor analysis should be applied to more than 300 samples (Çokluk, Şekercioğlu, \& Büyüköztürk, 2012). The obtained data was analyzed through principal axis factoring method and the Promax rotation technique. Variables with sampling sufficiency values less than 0.4 , single variables under specific factors, variables which are under multiple factors and at the same time have factor load differences less than 0.1 were excluded from the study and 10 different dimensions were obtained as a result of the factor analysis, each of them having eigenvalues over 1. Internal consistency of factors was measured by using the Cronbach's Alpha $(\alpha)$ value. The rate of variance explained as a result of the EFA is $69 \%$. Internal consistency and explained variance rates of the factors, KMO values associated with the data set and significance level are given in Table 1.

Following the determination of factors that have influence over consumers' adoption of shopping via mobile applications by EFA, the research model given in Figure 1 was developed in order to test relations of these factors with the structures of Attitude, Behavioral Intention and Behavior. The relations within the scope of this study were tested with Smart PLS software using bootstrapping resampling method. Relations within the model were tested at a significance level of 0.01 . The path coefficients and $T$ values in the research model are located in Table 3. The conceptual model developed through the analyses conducted with Smart PLS software and used to explain consumers' adoption of shopping via mobile applications is given in Figure 2. 
When the external loads of latent variables determined by the analysis are examined, it is seen that all variables belonging to the structure of behavior are over 0.6 except for one (B2:0,409). Some experts of psychometrics (Churchill, 1979) suggest that reflective indicators with standardized outer loads less than 0.4 should be excluded from the model. The lowest behavioral variable was not excluded from the model as its load was over the limit. Composite Reliability (CR) value is expected to be over 0.7 within the first phase of the study and over 0.8 or 0.9 during the following phases (Nunnally and Bernstein, 1994). When Table 1 is examined, it is seen that all CR values belonging to latent variables, except for Behavior (0.695), are over the value of 0.7. These results show that all latent variables used in this model are reliable.

In order to evaluate the validity, two subtypes should be analyzed. These are convergent validity and discriminant validity. It is recommended to use the Average Variance Extracted (AVE) for evaluation of the convergent validity (Fornell \& Larcker, 1981). The AVE value should be over 0.5. Table-1 shows that threshold coefficients of AVE values belonging to the latent variable are higher than 0.5 . Therefore convergent validity of the latent variable within this model was verified. It is also stated that as square roots of the AVE values belonging to latent variables can also be used for the discriminant validity, the square root values should be higher than the correlation value among latent variables (Fornell \& Larcker, 1981). The Fornell Larcker Criterion section, which is given in the report output of Smart PLS software, is also summarized in Table 4. The values written with boldface letters inside the Table indicate square roots of AVE scores belonging to latent variables. Table-3 verifies the discriminant validity of the measurement used in the study. The study uses the Variance Inflation Factor (VIF) to test the indicator variables that form the formative latent variables in terms of multicollinearity. As a rule, a VIF value over 10 indicates existence of harmful collinearity (Henseler \& Ringle, 2009). None of the indicators and latent variables used in this study has VIF values over 5 . Therefore, there is no problem with multicollinearity between indicator variables and latent variables used in the model.

The analysis conducted with Smart PLS software measures the path coefficients associated with the structures used in the model. Significance of these coefficients is evaluated by using the bootstrapping method. This method provides "t values" for each path prediction. All paths indicating relations among latent variables of the model developed by the study have significance values of 0.01 (Figure 2). The $\mathrm{R}^{2}$ value, which is the coefficient of determination for Behavior latent variable is 0.079 . Behavioral Intention latent variable of this model has an impact at the rate of 0.281 over the Behavior. Perceived Usefulness, Attitude and the Perceived Mobility altogether explain Behavioral Intention latent variable's variance, which is $63.8 \%$. Attitude $(0.604)$ has the strongest impact on Behavioral Intention within the model and it is followed by the Perceived Usefulness (0.167) and Perceived Mobility (0.141). Moreover, latent variables of Perceived Usefulness, Innovativeness, Personalization, Perceived Informativeness and Word of Mouth Communication altogether explain the Attitude latent variable's variance of $59.1 \%$. Latent variables which have impacts on Attitude are the Perceived Usefulness (0.342), Personalization (0.273), Word of Mouth Communication (0.190), the Perceived Informativeness (0.129) and Innovativeness (0.119). On the other hand, variance (47.1\%) of the latent variable belonging to the Perceived Usefulness is explained by latent variables of Subjective Norm and the Perceived Ease of Use. The Perceived Ease of Use (0.595) has the strongest impact on this latent variable and it is followed by Subjective Norm (0.231).

Table 1. Results of EFA and smart PLS

\begin{tabular}{|c|c|c|c|c|c|c|c|}
\hline & $\begin{array}{l}\text { EFA } \\
\text { Loadings }\end{array}$ & $\begin{array}{l}\text { Outer Loadings } \\
\text { (PLS) }\end{array}$ & $\begin{array}{l}\mathrm{R}^{2} \\
\text { (PLS) }\end{array}$ & $\begin{array}{l}\alpha \\
(\mathrm{EFA})\end{array}$ & $\begin{array}{l}\text { CR } \\
\text { (PLS) }\end{array}$ & $\begin{array}{l}\text { AVE } \\
\text { (PLS) }\end{array}$ & $\begin{array}{l}\text { VIF } \\
(\mathrm{PLS})\end{array}$ \\
\hline $\begin{array}{l}\text { Perceived Usefulness / Value ( } \alpha: 0.880 ; \text { VE: \% } \\
\text { 28.397) }\end{array}$ & & & \multirow{9}{*}{0.471} & \multirow{9}{*}{0.883} & \multirow{9}{*}{0.908} & \multirow{9}{*}{0.556} & 1.820 \\
\hline $\mathrm{PU}-1$ & 0.663 & 0.724 & & & & & 2.002 \\
\hline $\mathrm{PU}-2$ & 0.595 & 0.629 & & & & & 1.903 \\
\hline $\mathrm{PU}-3$ & 0.543 & 0.623 & & & & & 1.440 \\
\hline $\mathrm{PU}-4$ & 0.443 & 0.666 & & & & & 1.642 \\
\hline $\mathrm{PV}-1$ & 0.662 & 0.778 & & & & & 2.329 \\
\hline $\mathrm{PV}-2$ & 0.877 & 0.855 & & & & & 2.937 \\
\hline$P V-3$ & 0.999 & 0.835 & & & & & 2.908 \\
\hline $\mathrm{PV}-4$ & 0.825 & 0.812 & & & & & 2.513 \\
\hline $\begin{array}{l}\text { Innovativeness / Existing Knowledge ( } \alpha \text { : 0.838; } \\
\text { VE: \% 7.697) }\end{array}$ & & & & & & & 1.439 \\
\hline $\mathrm{INN}-1$ & 0.526 & 0.718 & 0.000 & 0.842 & 0.879 & 0.512 & 2.025 \\
\hline INN -2 & 0.729 & 0.803 & & & & & 2.643 \\
\hline
\end{tabular}




\begin{tabular}{|c|c|c|c|c|c|c|c|}
\hline $\mathrm{INN}-3$ & 0.678 & 0.780 & & & & & 2.095 \\
\hline $\mathrm{INN}-5$ & 0.678 & 0.636 & & & & & 1.997 \\
\hline $\mathrm{EN}-1$ & 0.652 & 0.644 & & & & & 1.466 \\
\hline $\mathrm{EN}-2$ & 0.585 & 0.671 & & & & & 1.576 \\
\hline $\mathrm{EN}-3$ & 0.688 & 0.739 & & & & & 2.137 \\
\hline Word of Mouth ( $\alpha$ : $0.842 ; \mathrm{VE}$ : \%5.365) & & & \multirow{5}{*}{0.000} & \multirow{5}{*}{0.845} & \multirow{5}{*}{0.895} & \multirow{5}{*}{0.682} & 1.637 \\
\hline WOM - 1 & 0.801 & 0.781 & & & & & 1.738 \\
\hline WOM - 2 & 0.809 & 0.882 & & & & & 2.388 \\
\hline WOM -3 & 0.769 & 0.868 & & & & & 2.324 \\
\hline WOM - 4 & 0.750 & 0.766 & & & & & 1.651 \\
\hline Perceived Mobility ( $\alpha: 0.841$; VE: \% 3.812) & & & \multirow{4}{*}{0.000} & \multirow{4}{*}{0.844} & \multirow{4}{*}{0.905} & \multirow{4}{*}{0.761} & 1.414 \\
\hline $\mathrm{PM}-1$ & 0.738 & 0.848 & & & & & 1.890 \\
\hline $\mathrm{PM}-2$ & 0.682 & 0.892 & & & & & 2.022 \\
\hline $\mathrm{PM}-3$ & 0.879 & 0.876 & & & & & 2.197 \\
\hline Personalization ( $\alpha$ : 0.819; VE: \% 3.405) & & & \multirow{4}{*}{0.000} & \multirow{4}{*}{0.824} & \multirow{4}{*}{0.895} & \multirow{4}{*}{0.739} & 1.288 \\
\hline PER -1 & 0.857 & 0.866 & & & & & 2.150 \\
\hline PER -2 & 0.762 & 0.871 & & & & & 2.051 \\
\hline PER -3 & 0.660 & 0.841 & & & & & 1.622 \\
\hline $\begin{array}{l}\text { Perceived Informativeness ( } \alpha: 0.835 ; \text { VE: \% } \\
\text { 3.252) }\end{array}$ & & & \multirow{4}{*}{0.000} & \multirow{4}{*}{0.840} & \multirow{4}{*}{0.903} & \multirow{4}{*}{0.756} & 1.558 \\
\hline $\mathrm{PI}-1$ & 0.771 & 0.876 & & & & & 2.387 \\
\hline $\mathrm{PI}-2$ & 0.781 & 0.881 & & & & & 2.447 \\
\hline $\mathrm{PI}-3$ & 0.715 & 0.852 & & & & & 1.638 \\
\hline Perceived Ease of Use ( $\alpha: 0.766 ;$ VE: \% 3.115) & & & \multirow{5}{*}{0.142} & \multirow{5}{*}{0.778} & \multirow{5}{*}{0.855} & \multirow{5}{*}{0.598} & 1.057 \\
\hline PEOU - 1 & 0.612 & 0.761 & & & & & 1.495 \\
\hline PEOU - 3 & 0.568 & 0.835 & & & & & 1.627 \\
\hline PEOU - 4 & 0.744 & 0.660 & & & & & 1.382 \\
\hline PEOU -5 & 0.619 & 0.826 & & & & & 1.705 \\
\hline Subjective Norm ( $\alpha$ : 0.874; VE: \% 2.719 ) & & & \multirow{3}{*}{0.000} & \multirow{3}{*}{0.876} & \multirow{3}{*}{0.941} & \multirow{3}{*}{0.889} & 1.057 \\
\hline $\mathrm{SN}-1$ & 0.784 & 0.952 & & & & & 2.542 \\
\hline $\mathrm{SN}-2$ & 0.878 & 0.934 & & & & & 2.542 \\
\hline Attitude & & & \multirow{4}{*}{0.591} & & & & 1.672 \\
\hline ATT -1 & - & 0.930 & & 0804 & 0886 & 0726 & 3.628 \\
\hline ATT -2 & - & 0.930 & & 0.804 & 0.886 & 0.726 & 3.645 \\
\hline ATT -3 & - & 0.670 & & & & & 1.269 \\
\hline Behavioral Intention & & & & & & & 1.000 \\
\hline $\mathrm{BI}-1$ & - & 0.890 & & & & & 2.672 \\
\hline $\mathrm{BI}-2$ & - & 0.951 & 0.638 & 0.902 & 0.939 & 0.836 & 4.610 \\
\hline $\mathrm{BI}-3$ & - & 0.901 & & & & & 3.005 \\
\hline Behavior & & & & & & & - \\
\hline B1 & - & 0.988 & 0.079 & - & 0.695 & 0.572 & 1.076 \\
\hline B2 & - & 0.409 & & & & & 1.076 \\
\hline
\end{tabular}

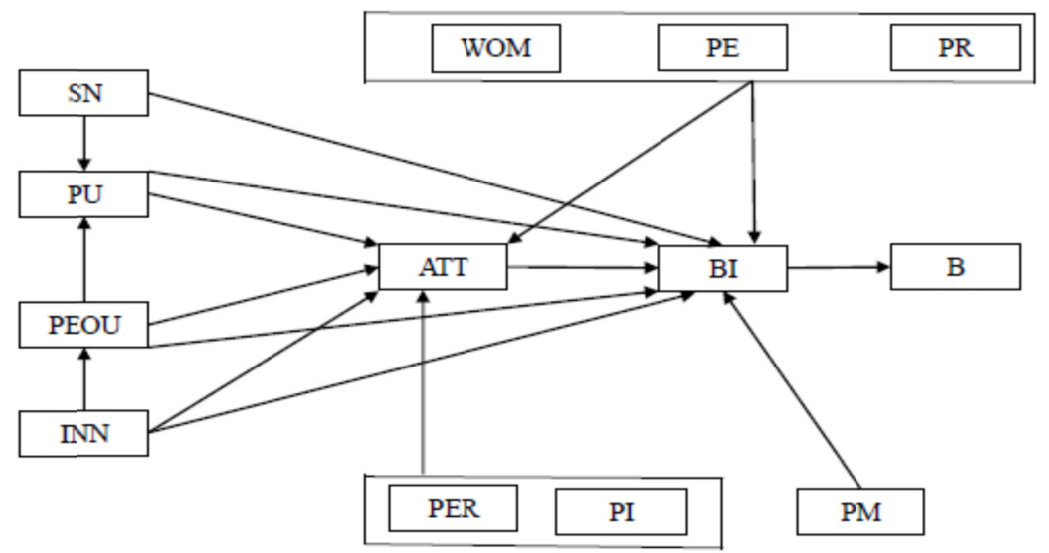

Figure 1. Research model 
Table 2. Data of research sample and descriptives

\begin{tabular}{|c|c|c|c|c|c|}
\hline Gender & Frequency & Percentage & Mobile Shopping Areas done via Apps & Fre. & Per. \\
\hline Female & 181 & 42 & General/ Private Shopping & 377 & 26 \\
\hline Male & 256 & 58 & Second Hand Trading & 121 & 8 \\
\hline Age & & & Mobile Couponing & 118 & 8 \\
\hline $17-25$ & 44 & 10 & Plain Ticket & 287 & 19 \\
\hline $26-36$ & 278 & 64 & Book & 206 & 14 \\
\hline $37-47$ & 97 & 22 & Food & 192 & 14 \\
\hline 48 and over & 19 & 4 & Vacation & 168 & 11 \\
\hline Income & & & Daily Duration of Using Mobile Shopping Apps & & \\
\hline 1400 TRY and below & 77 & 17 & Lower than 10 minutes & 196 & 45 \\
\hline $1401-2500 \mathrm{TRY}$ & 84 & 19 & Lower than 30 minutes & 157 & 36 \\
\hline 2501-4500TRY & 48 & 11 & Lower than 1 hour & 66 & 15 \\
\hline 4501-7000TRY & 65 & 15 & 1 to 3 hours & 19 & 4 \\
\hline 7001TRY and over & 165 & 38 & & & \\
\hline Education & & & Number of Mobile Shopping Using Apps & & \\
\hline Primary School & 5 & 1.1 & Once every 6 months & 65 & 15 \\
\hline High School & 25 & 5.7 & Once every 3 months & 60 & 14 \\
\hline Associate's Degree/College & 271 & 61.9 & Once every 2 months & 46 & 10 \\
\hline \multirow[t]{3}{*}{ Postgraduate } & 137 & 31.3 & Once every month & 101 & 23 \\
\hline & & & 2 to 5 every month & 145 & 33 \\
\hline & & & 2 to 5 every week & 21 & 5 \\
\hline
\end{tabular}

Table 3. Path coefficients and T values of the research model

\begin{tabular}{|c|c|c|}
\hline Relationships & Path Coefficients & T Statistics \\
\hline $\mathrm{BI}->\mathrm{B}$ & 0.281 & $6.283^{* *}$ \\
\hline ATT $->$ BI & 0.604 & $12.483 * *$ \\
\hline INN -> BI & 0.125 & 0.512 \\
\hline PEOU -> BI & 0.048 & 1.063 \\
\hline $\mathrm{PE}->\mathrm{BI}$ & 0.041 & 0.017 \\
\hline $\mathrm{PR}->\mathrm{BI}$ & -0.141 & 0.931 \\
\hline $\mathrm{PM}->\mathrm{BI}$ & 0.141 & $3.441 * *$ \\
\hline PU -> BI & 0.167 & $3.395^{* *}$ \\
\hline $\mathrm{SN}->\mathrm{BI}$ & -0.007 & 0.590 \\
\hline WOM -> BI & 0.117 & 1.300 \\
\hline PE -> ATT & 0.061 & 1.447 \\
\hline INN -> ATT & 0.119 & $2.755^{* *}$ \\
\hline PEOU $->$ ATT & -0.010 & 0.207 \\
\hline PER -> ATT & 0.273 & $7.007^{* *}$ \\
\hline PI -> ATT & 0.129 & $2.735^{* *}$ \\
\hline PR -> ATT & -0.162 & 1.120 \\
\hline PU -> ATT & 0.342 & $7.538^{* *}$ \\
\hline WOM -> ATT & 0.190 & $4.464 * *$ \\
\hline PEOU -> PU & 0.595 & $13.799 * *$ \\
\hline $\mathrm{SN}->\mathrm{PU}$ & 0.231 & $6.136^{* *}$ \\
\hline INN $->$ PEOU & 0.377 & $7.684^{* *}$ \\
\hline
\end{tabular}

Note. ${ }^{*} \mathrm{p}<0.05 .{ }^{* *} \mathrm{p}<0.01$.

Table 4. Correlation between constructs

\begin{tabular}{|c|c|c|c|c|c|c|c|c|c|c|c|}
\hline $\begin{array}{l}\text { Research } \\
\text { Constructs }\end{array}$ & ATT & $\mathrm{B}$ & BI & INN & PEOU & PER & PI & $\mathrm{PM}$ & PU & SN & WOM \\
\hline ATT & 0.852 & & & & & & & & & & \\
\hline B & 0.292 & 0.756 & & & & & & & & & \\
\hline BI & 0.771 & 0.281 & 0.914 & & & & & & & & \\
\hline INN & 0.483 & 0.244 & 0.423 & 0.716 & & & & & & & \\
\hline PEOU & 0.443 & 0.114 & 0.477 & 0.377 & 0.773 & & & & & & \\
\hline PER & 0.535 & 0.138 & 0.413 & 0.330 & 0.214 & 0.860 & & & & & \\
\hline PI & 0.537 & 0.116 & 0.488 & 0.373 & 0.430 & 0.384 & 0.870 & & & & \\
\hline PM & 0.450 & 0.209 & 0.499 & 0.458 & 0.495 & 0.239 & 0.446 & 0.872 & & & \\
\hline PU & 0.614 & 0.225 & 0.611 & 0.379 & 0.648 & 0.283 & 0.507 & 0.513 & 0.745 & & \\
\hline $\mathrm{SN}$ & 0.331 & 0.015 & 0.283 & 0.265 & 0.233 & 0.117 & 0.296 & 0.292 & 0.370 & 0.943 & \\
\hline WOM & 0.569 & 0.245 & 0.433 & 0.504 & 0.345 & 0.400 & 0.450 & 0.365 & 0.445 & 0.281 & 0.826 \\
\hline
\end{tabular}


Lastly the formula given below was used to measure goodness of fit value of the model (Tenenhaus, Vinzi, Chatelin, \& Lauro, 2005):

$\mathrm{GoF}=\sqrt{\overline{A V E} * \overline{R^{2}}}$

According to the formula above, goodness of fit $(\mathrm{GoF})$ value of the model was measured as 0.51 and this value (Wetzels, Odekerken-Schröder, \& Van Oppen, 2009) was identified as over the threshold value which is 0.36 . This result shows that the model has a good overall fit.

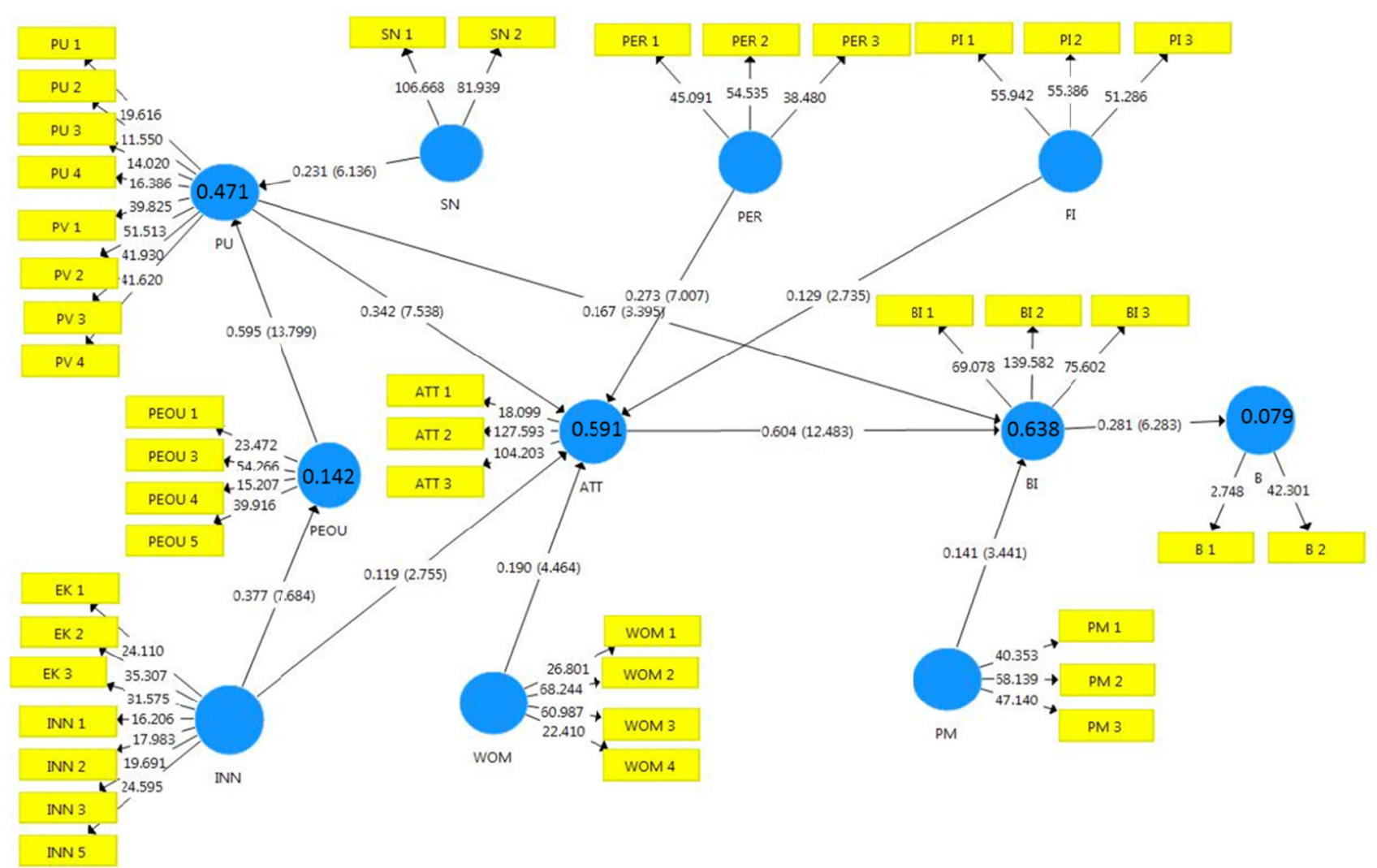

Figure 2. The developed model for consumers' adoption of shopping via mobile application

Note. Figure includes values of $\mathrm{R}^{2}$, path coefficients and $\mathrm{T}$ values; $\mathrm{p}<0.01$ for all paths.

\section{Discussion of Results}

The factors behind consumers' adoption of shopping via mobile applications were explained in 10 different dimensions in line with the results of EFA conducted within the scope of this study. These dimensions are Perceived Usefulness, Innovativeness, Perceived Entertainment, Word of Mouth Communication, Perceived Risk, Perceived Mobility, Personalization, Perceived Informativeness, Perceived Ease of Use and Subjective Norm. All the dimensions obtained through EFA are reliable. The rate of variance explained as a result of EFA is $69 \%$. On the other hand, it is seen that variables of Perceived Usefulness and Perceived Value are classified under the same factor. With reference to the fact that variables belonging to both of the aforementioned factors are in a close relationship with each other, it can be inferred that only one of the latent variables could be enough for the measurement. This inference also applies to Innovativeness and Existing Knowledge factors.

Coefficients of determination $\left(\mathrm{R}^{2}\right)$, path coefficients and significance values associated with Smart PLS software developed within the scope of this study are given in Figure 2. In marketing researches, 0.75 is considered as a satisfying level for coefficient of determination $\left(\mathrm{R}^{2}\right)$, while 0.50 is considered as acceptable and 0.25 as weak (Wong, 2013). $\mathrm{R}^{2}$ values of this study on the model which explains consumers' adoption of shopping via mobile applications are approximately $8 \%$ for Behavior, $64 \%$ for Behavioral Intention, $59 \%$ for Attitude and lastly $47 \%$ for Perceived Usefulness. It is seen from these results that Behavioral Intention, Attitude and the Perceived Usefulness structures have acceptable $\mathrm{R}^{2}$ values, while Behavior structure has a weak one. On the other side, all 
of relations established by internal latent variables in this model are significant.

When the model developed in this study is examined within the context of relations among conceptual structures analyzed by previous studies in the literature, it is identified that Innovativeness (Pagani, 2004; Gao, Rohm, Sultan, \& Pagani, 2013), Perceived Informativeness (Bauer, Reichardt, Barnes, \& Neumann, 2005; Okazaki, 2007) and Personalization (Chellappa \& Sin, 2005; Xu, 2006) have significant relations with Attitude, similar to the studies within the relevant literature. On the other hand, Attitude (Ajzen \& Fishbein, 1975) and Perceived Mobility (Hong, Thong, Moon, \& Tam, 2008; Faziharudean \& Li-Ly, 2011) have significant relations with Behavioral Intention parallel to the existing literature. Perceived Usefulness also has significant relations with both Attitude and Behavioral Intention as in TAM. Again in parallel with the previous studies, Behavioral Intention has a significant relation with Behavior as in the Theory of Reasoned Action. Differently from the data of previous studies within the literature (Nysveen, Pedersen, \& Thorbjørnsen, 2005; Bauer, Reichardt, Barnes, \& Neumann, 2005; Wu \& Wang, 2005), Perceived Entertainment and Perceived Risk structures, both of which were obtained through EFA conducted during the analysis process, have significant relations with neither Attitude nor Behavioral Intention. As it is also seen in previous studies within the literature, Innovativeness is in a significant relationship with Perceived Ease of Use, whereas Subjective Norm and Perceived Ease of Use are in a similar relation with Perceived Usefulness (Davis, Bagozzi, \& Warshaw, 1989; Yang, 2005; Yang, 2005; Bhatti, 2007).

\section{Conclusions}

The present study has some significant findings from Turkish culture about consumers' adoption of shopping via mobile applications. Structures such as Personalization, Word of Mouth Communication and Perceived Mobility used in the model developed within the scope of this research, but rarely used in this field of studies, were verified to be determinants of shopping behavior via mobile applications. Considering today's marketing approach to customize products and services in line with individual wishes and needs, it seems highly natural that personalization may be a determining factor for adoption of mobile applications. Therefore users of mobile shopping applications who have positive attitudes would be more willing to share their personal information to benefit customized offers. In the information age we are in, consumers want to bring together all the information they can obtain about products and services before making purchase decision for choosing the best option. In this regard, consumers are highly affected by comments and evaluations of those who have previously experienced a specific product, service or application. High sensitivity toward bandwidth, data transmission rates and geographical locations are among limiting factors for mobile applications' ability to perform functions. The concept of mobility, which expresses the perception of "everytime and everywhere", shows the expectations of consumers from products and services in a specific place and time interval. That's why to overcome these limiting factors would enhance the perception of mobility. Considering the developed model and factors affecting consumer adoption of shopping via mobile applications such as personalization, word of mouth communication and perceived mobility can give firms to gain a sustainable competitive advantage in a digital world. The results of the study are considered to beneficial for mobile application developers who are independent individuals and professional organizations like brands.

\section{Limitations and Future Research}

Some possible semantic and verbal mistakes in translation of variables given in survey forms from English to Turkish are considered among limitations of the study. The developing but not settled structure of the market associated with mobile technologies in Turkey is another limitation. On the other hand; as the research model was developed in consideration of relations within the literature, Attitude, Intention and Behavior concepts were not included in the exploratory factor analysis.

Considering the relatively low level of mobile shopping in Turkey, where numbers of smart phone users and mobile broadband subscribers are rather high, further studies to identify the determinants and explain the behavior in question with larger samples from different regions are needed in purpose of ensuring diffusion of mobile shopping in Turkey.

\section{References}

Afthanorhan, A., \& Afthanorhan, B. W. (2013). A Comparison of Least Square Structural Equation Modeling (PLS-SEM) and Covariance Based Structural Equation Modeling (CB-SEM) for Confirmatory Factor Analysis. International Journal of Engineering Science and Innovative Technology, 2(5), 198-204.

Agrebi, S., \& Jallais, J. (2015). Explain the intention to use smartphones for mobile shopping. Journal of Retailing and Consumer Services, 22, 16-23. https://doi.org/10.1016/j.jretconser.2014.09.003 
Ahn, T., Ryu, S., \& Han, S. I. (2004). The impact of the online and offline features on the user acceptance of Internet shopping malls. Electronic Commerce Research and Applications, 3(4), 405-420. https://doi.org/10.1016/j.elerap.2004.05.001

Ajzen, I., \& Fishbein, M. (1980). Understanding Attitudes and Predicting Social Behavior. New Jersey Prentice-Hall Inc, USA.

Ajzen. I. (1991). The theory of planned behavior. Organizational Behavior and Human Decision Processes, 50(2) 179-211. https://doi.org/10.1016/0749-5978(91)90020-T

Aldas-Manzano, J., Ruiz-Mafe, C., \& Sanz-Blas, S. (2009). Exploring individual personality factors as drivers of M-shopping acceptance. Industrial Management and Data Systems, 109(6), 739-757. https://doi.org/10.1108/02635570910968018

Al-Meshal, S. A., \& Almotairi, M. A. (2013). Consumer Acceptance of Mobile Marketing: An Empirical Study on the Saudi Female. International Journal of Marketing Studies, 5(5), 94-100. http://dx.doi.org/10.5539/ijms.v5n5p94

Assaurt, R., \& Eiamkanchanalai, S. (2015). Consumption Values, Personal Characteristics and Behavioral Intentions in Mobile Shopping Adoption. Faculty of Economics and Business, University of Zagreb. Trište Journal, 27(1), 21-41.

Bagozzi, R. P., \& Yi, Y. (1988). On the evaluation of structural equation models. Journal of the Academy of Marketing Science, 16(1), 74-94. https://doi.org/10.1007/BF02723327

Bankalararası Kart Merkezi (BKM). (2016). Türkiye Online Ödemeler Raporu. Retrieved from $\mathrm{http}: / / \mathrm{bkm} . c o m . t r / t u r k i y e-o n l i n e-o d e m e l e r-r a p o r u /$

Barutçu, S. (2007). Attitudes towards mobile marketing tools: A study of Turkish consumers. Journal of Targeting, Measurement and Analysis for Marketing, 16, 26-38. https://doi.org/10.1057/palgrave.jt.5750061

Barutçu, S. (2008). Consumers' Attitudes towards Mobile Marketing and Mobile Commerce in Consumer Markets. Ege Academic Review, 8(1), 15-32.

Barutçu, S., \& Göl, M. Ö. (2009). Mobil Reklamlar ve Mobil Reklam Araçlarına Yönelik Tutumlar. KMU İ̈BF Dergisi, 11(17), 24-41.

Bauer, H., H., Reichardt, T., Barnes, S. J., \& Neumann, M. M. (2005). Driving consumer acceptance of mobile marketing: A theoretical framework and empirical study. Journal of Electronic Commerce Research, 6(3), 181-192.

Bhattacherjee, A. (2000). Acceptance of E-commerce Services: The Case of Electronic Brokerages. IEEE Transactions on Systems, Man and Cybernetics, 30, 411-420. https://doi.org/10.1109/3468.852435

Bhatti, T. (2007). Exploring factors influencing the adoption of mobile commerce. Journal of Internet Banking and Commerce, 12(3), 2-13.

Bigné, E., Ruiz, C., \& Sanz, S. (2007). Key drivers of mobile commerce adoption: An exploratory study of Spanish mobile users. Journal of Theoretical and Applied Electronic Commerce Research, 2(2), 48-61.

Chellappa, R. K., \& Sin, R. G. (2005). Personalization versus Privacy: An Empirical Examination of the Online Consumer's Dilemma. Information Technology and Management, 6, 181-202. https://doi.org/10.1007/s10799-005-5879-y

Chiem, R., Arriola, J., Browers, D., Gross, J., Limman, E., Nguyen, P. V., \& Seal, K. C. (2010). The Critical Success Factors for Marketing with Downloadable Applications: Lessons Learned from Selected European Countries. International Journal of Mobile Marketing, 5(2), 43-56.

Chinomona, R., \& Sandada, M. (2013). The Influence of Market Related Activities on the Acceptance of Mobile Marketing and Consumer Intention to Purchase Products Promoted by SMS in South Africa. The Journal of Applied Business Research, 29(6), 1897-1908. https://doi.org/10.19030/jabr.v29i6.8225

Chong, A. Y. L., Chan, F. T. S., \& Ooi, K. B. (2012). Predicting consumer decisions to adopt mobile commerce: Cross country empirical examination between China and Malaysia. Decision Support Systems, 53, 34-43. https://doi.org/10.1016/j.dss.2011.12.001

Churchill, G. A. (1979). A paradigm for developing better measures of marketing constructs. Journal of Marketing Research, 16(1), 64-73. https://doi.org/10.2307/3150876

Çokluk, Ö., Şekercioğlu, G., \& Büyüköztürk, Ş. (2012). Sosyal Bilimleri için Çok Değişkenli İstatistik: SPSS ve 
LISREL Uygulamaları. 2.Bask1, Pegem Akademi, Ankara.

Davis, F. D., Bagozzi, R. P., \& Warshaw, P. R. (1989). User Acceptance of Computer Technology: A Comparison of Two Theoretical Models. The Institute of Management Science, 35(8), 982-1002. https://doi.org/10.1287/mnsc.35.8.982

Du, H., Zhu, G., Zhao, L., \& Lv, T., (2012). An emprical study of consumer adoption on $3 \mathrm{G}$ value-added services in China. Nankai Business Review International, 3(3), 257-283. https://doi.org/10.1108/20408741211264576

EMarketer. (2014). 2 Billion Consumers Worldwide to Get Smart(phones) by 2016. Retrieved from https://www.emarketer.com/Article/2-Billion-Consumers-Worldwide-Smartphones-by-2016/1011694

Faziharudean, T. M., \& Li-Ly, T. (2011). Consumers' behavioral intentions to use mobile data services in Malaysia. African Journal Business Management, 5(5), 1811-1821. https://doi.org/10.5897/AJBM10.794

Flynn, L. R., \& Goldsmith, R. E. (1999). A Short, Reliable Measure of Subjective Knowledge. Journal of Business Research, 46, 57-66. https://doi.org/10.1016/S0148-2963(98)00057-5

Fornell, C., \& Larcker, D. F. (1981). Structural equation models with unobservable variables and measurement error: Algebra and statistics. Journal of Marketing Research, 18(3), 328-388. http://dx.doi.org/10.2307/3150980

Gao, T., Rohm, A. J., Sultan, F., \& Huang, S. (2012). Antecedents of Consumer Attitudes Towards Mobile Marketing: A Comparative Study of Youth Markets in the US and China. Thunderbird International Business Review, 54(2), 211-224. http://dx.doi.org/10.1002\%2Ftie.21452

Gao, T., Rohm, A. J., Sultan, F., \& Pagani, M. (2013). Consumers un-tethered: A three-market empirical study of consumers' mobile marketing acceptance. Journal of Business Research, 66, 2536-2544. https://doi.org/10.1016/j.jbusres.2013.05.046

Gao, T., Sultan, F., \& Rohm, A. J. (2010). Factors influencing Chinese youth consumers' acceptance of mobile marketing. Journal of Consumer Marketing, 27(7), 574-583. https://doi.org/10.1108/07363761011086326

Goldsmith, R. E., \& Hofacker, C. F. (1991). Measuring consumer innovativeness. Journal of the Academy of Marketing Science, 19(3), 209-21. https://doi.org/10.1007/BF02726497

Hair, J. F., Sarstedt, M., Ringle, C. M., \& Mena, J. A. (2012). An assessment of the use of partial least squares structural equation modeling in marketing research. Journal of the Academy of Marketing Science, 40(3), 414-433. https://doi.org/10.1007/s11747-011-0261-6

Henseler, J., \& Ringle, C. M. (2009). The Use of Partial Least Squares Path Modeling, in International Marketing. New Challenges to International Marketing Advances in International Marketing, 20, 277-319. http://dx.doi.org/10.1108/S1474-7979(2009)0000020014

Hong, S J., Thong, J. Y. L., Moon, J. Y., \& Tam, K. Y. (2008). Understanding the behavior of mobile data services consumers. Information Systems Frontiers, 10, 431-445. https://doi.org/10.1007/s10796-008-9096-1

Hung, S. Y., \& Chang, C. M. (2005). User acceptance of WAP services: test of competing theories. Computer Standards and Interfaces, 27, 359-370. User acceptance of WAP services: test of competing theories. https://doi.org/10.1016/j.csi.2004.10.004

Information and Communication Technologies Authority. (2017). Bulletin on Electronic Communications Statistics at Provincial Level 2017. Retrieved from https://www.btk.gov.tr/File/?path=ROOT\%2f1\%2fDocuments\%2fSayfalar\%2fIl_Istatistikleri\%2fEhsyib_(2 011-2016).pdf

Information and Communication Technologies Authority. (2017). ELECTRONIC COMMUNICATIONS MARKET IN TURKEY MARKET DATA (2017 Q1). Retrieved from https://www.btk.gov.tr/File/?path=ROOT\%2f1\%2fDocuments\%2fPages\%2fMarket_Data\%2f2017_Q1_Eng .pdf

Jarvenpaa, S. L., Lang, K. R., Takeda, Y., \& Tuunainen, V. K. (2003). Mobile commerce at crossroads. Communications of the ACM, 46(12), 41-44. http://dx.doi.org/10.1145/953460.953485

James, S. J., Thong, J. Y. L., Moon, J. Y., \& Tam, K. Y. (2008). Understanding the behavior of mobile data services consumers. Inf Syst Front., 10, 431-445. https://doi.org/10.1007/s10796-008-9096-1 
Khalifa, M., \& Shen, K. N. (2008). Drivers for Transactional B2C M-Commerce Adoption: Extended Theory of Planned Behavior. Journal of Computer Information Systems, 111-117.

Kim, B. (2012). The diffusion of mobile data services and applications: Exploring the role of habit and its antecedents. Telecommunication Policy, 36, 69-84. https://doi.org/10.1016/j.telpol.2011.11.011

Kim, B., \& Han, I. (2009). What drives the adoption of mobile data services? An approach from a value perspective. Journal of Information Technology, 24, 35-45. https://doi.org/10.1057/jit.2008.28

Kim, H., Chan, H. C., \& Gupta, S. (2007). Value-based adoption of mobile internet: An empirical investigation. Decision Support Systems, 43(1), 111-126. https://doi.org/10.1016/j.dss.2005.05.009

Kleijnen, M., Ruyter, K., \& Wetzels, M. (2004). Consumer adoption of wireless services: Discovering the rules, while playing the game. Journal of Interactive Marketing, 18(2), 51-62. https://doi.org/10.1002/dir.20002

Kumar, A., \& Mukherjee, A. (2013). Shop While You Talk: Determinants of Purchase Intentions Through A Mobile Device. International Journal of Mobile Marketing, 8(1), 23-37.

Leppäniemi, M., \& Karjaluoto, H. (2005). Factors Influencing Consumers' Willingness to Accept Mobile Advertising: A Conceptual Model. International Journal of Mobile Communications, 3(3), 197-213. https://doi.org/10.1504/IJMC.2005.006580

Leppäniemi, M., Sinisalo, J., \& Karjaluoto, H. (2006). A Review of Mobile Marketing Research. International Journal of Mobile Marketing, 1(1), 30-40.

Lin, C. H., Sher, P. J., \& Shih, H. Y. (2005). Past progress and future directions in conceptualizing customer perceived value. International Journal of Service Industry Management, 16(3-4), 318-336. https://doi.org/10.1108/09564230510613988

Lopez-Nicolas, C., Molina-Castillo, F. J., \& Bouwman, H. (2008). An assessment of advanced mobile services acceptance: Contributions from TAM and diffusion theory models. Information and Management, 45(6), 359-364. https://doi.org/10.1016/j.im.2008.05.001

Lu, H. P., \& Su, Y. J. (2009). Factors affecting purchase intention on mobile shopping web sites. Internet Research, 19(4), 442-458. https://doi.org/10.1108/10662240910981399

Lu, J., Liu, C., Yu, C. S., \& Wang, K. (2008). Determinants of accepting wireless mobile data services in China. Information Management, 45, 52-64. https://doi.org/10.1016/j.im.2007.11.002

Luarn, P., \& Lin, H. (2005). Toward an understanding of the behavioral intention to use mobile banking. Computers in Human Behavior, 21, 873-891. https://doi.org/10.1016/j.chb.2004.03.003

Mahatanankoon, P., Wen, H. J., \& Lim, B. (2005). Consumer-based m-commerce: exploring consumer perception of mobile applications. Computer Standards \& Interfaces, 27(4), 347-357. https://doi.org/10.1016/j.csi.2004.10.003

Merisavo, M., Kajalo, S., Karjaluoto, H., Virtanen, V., Salmenkivi, S., Raulas, M., \& Leppäniemi, M. (2007). An Emprical Study of the Drivers of Consumer Acceptance of Mobile Advertising. Journal of Interactive Advertising, 7(2), 41-50. https://doi.org/10.1080/15252019.2007.10722130

Mittal, B., \& Walfried, M. L. (1996). The Role of Personalization in Service Encounters. Journal of Retailing, 72 , 1, 95-109. https://doi.org/10.1016/S0022-4359(96)90007-X

Moore, G. C., \& Benbasat, I. (1991). Development of an instrument to measure the perceptions of adopting an information technology innovation. Information Systems Research, 2, 192-222. http://dx.doi.org/10.1287/isre.2.3.192

Moore, G. C., \& Benbasat, I. (1993). An Empirical Examination of a Model of Factors Affecting Utilization of Information Technology by End-Users. Working Paper, University of British Columbia, Faculty of Commerce.

Ngai, E. W. T., \& Gunasekaran, A. (2007). A review for mobile commerce research and applications. Decision Support System, 43, 3-15. https://doi.org/10.1016/j.dss.2005.05.003

Nunnally, J. C., \& Bernstein, I. H. (1994). Psychometric theory (3rd ed.). NewYork, NY: McGraw-Hill.

Nysveen, H., Pedersen, P. E., \& Thorbjørnsen, H. (2005). Intentions to use mobile services: Antecedents and cross-service comparisons. Journal of the Academy of Marketing Science, 33(3), 330-347. https://doi.org/10.1177/0092070305276149 
Okazaki, S. (2007). Lessons learned from i-mode: What makes consumers click wireless banner ads? Computers in Human Behavior, 23, 1692-1719. https://doi.org/10.1016/j.chb.2006.03.018

Özgüven, N. (2013). Tüketicilerin Mobil Reklamcıllğı Kabullenmelerinde Etkili Olan Faktörler Üzerine Bir Uygulama. Yönetim Bilimleri Dergisi, 11(21), 7-28.

Pagani, M. (2004). Determinants of adoption of third generation mobile multimedia services. Journal of Interactive Marketing, 18(3), 46. https://doi.org/10.1002/dir.20011

Parasuraman, A. (2000). Technology readiness index (TRI) A Multiple-Item Scale to Measure Readiness to Embrace New Technologies. Journal of Service Research, 2(4), 307-320. https://doi.org/10.1177/109467050024001

Park, J., \& Yang, S. J. (2006). The moderating role of consumer trust and experiences: Value driven usage of mobile technology. International Journal of Mobile Marketing, 1(2), 24-32.

Purcell, K. (2011). Half of adult cell phone owners have apps on their phones. Retrieved from http://www.pewinternet.org/files/old-media//Files/Reports/2011/PIP_Apps-Update-2011.pdf

Rao, S., \& Troshani, I. (2007). A Conceptual Framework and Propositions for the Acceptance of Mobile Services. Journal of Theoretical and Applied Commerce Research, 2(2), 61-73.

Rogers, E. M. (1995). Diffusion of Innovation. New York: The Free Press.

Rogers, E. M., \& Shoemaker, F. F. (1971). Communication of Innovations; A Cross-Cultural Approach. New York: The Free Press.

Rui-jin, Z., \& Xiang-yang, L. (2012). Research on Consumers' Attitudes and Acceptance Intentions toward Mobile Marketing. International Conference on Management Science and Engineering (19th). Dallas, USA, 2012, 727-732.

Ryu, J. S., \& Murdock, K. (2013). Consumer Acceptance of Mobile Marketing communications using the QR code. Journal of Direct, Data and Digital Marketing Practice, 15(2), 111-124. https://doi.org/10.1057/dddmp.2013.53

Shimp, T. A., \& Kavas, A. (1984). The Theory of Reasoned Action Applied to Coupon Usage. Journal of Consumer Research, 11(3), 795-809. http://dx.doi.org/10.1086/209015

Sirdeshmukh, D., Singh, J., \& Sabol, B. (2002). Consumer trust, value, and loyalty in relational exchanges. Journal of Marketing, 66(1), 15-37. https://doi.org/10.1509/jmkg.66.1.15.18449

Ström, R., Vendel, M., \& Bredican, J. (2014). Mobile Marketing: A literature review on its value for consumers. Journal of Retailing and Consumer Services, 21, 1001-1012. https://doi.org/10.1016/j.jretconser.2013.12.003

Sultan, F., Rohm, A. J., \& Gao, T. (2008). Factors Influencing Consumer Acceptance of Mobile Marketing: A Two-Country Study of Youth Markets. Journal of Interactive Marketing, 23, 308-320. https://doi.org/10.1016/j.intmar.2009.07.003

Şahin, A., \& Aytekin, P. (2012). Üniversite Öğrencilerinin Mobil Reklamlara Yönelik Tutumlarının İzinli Pazarlama Ekseninde İncelenmesi. Celal Bayar Üniversitesi, İ̈BF, Yönetim ve Ekonomi, 19(2), 17-36.

Taylor, S., \& Todd, P. A. (1995). Understanding Information Technology Usage: A Test of Competing Models. Information Systems Research, 6(2), 144-176. https://doi.org/10.1287/isre.6.2.144

Tenenhaus, M., Vinzi, V. E., Chatelin, Y. M., \& Lauro, C. (2005). PLS Path Modeling. Computational Statistics \& Data Analysis, 48(1), 159-205. https://doi.org/10.1016/j.csda.2004.03.005

Tornatzky, L. G., \& Klein, K. J. (1982). Innovation Characteristics and Innovation Adoption-Implementation: A Meta-Analysis of Findings. IEEE Transactions on Engineering Management, 29(1), 28-45. https://doi.org/10.1109/TEM.1982.6447463

Turel, O., Serenko, A., \& Bontis, N. (2007). User acceptance of wireless short messaging services: Deconstructing perceived value. Information and Management, 63-73. https://doi.org/10.1016/j.im.2006.10.005

Turel, O., Serenko, A., \& Bontis, N. (2010). User acceptance of hedonic digital artifacts: A theory of consumption values perspective. Information and Management, 63-73. https://doi.org/10.1016/j.im.2009.10.002 
Uğur, N. C., \& Türkmen, M. (2014). Tüketicilerin Mobil Uygulamaları Kabulüne Yönelik Bir Model Önerisi. 12.Uluslararassı Bilgi, Ekonomi ve Yönetim Kongresi Bildirileri Kitabı, 567-583.

Usta, R. (2009). Üniveriste Öğrencilerinin Mobil Reklamcıllğa Karşı Tutumları. Doğuş Üniversitesi Dergisi, 10(2), 294-309.

Uygun, M., Divanoğlu, S. U., \& Özçifçi, V. (2012). Mobil Pazarlama Uygulamalarına Yönelik Tüketici Kabulünü Etkileyen Faktörler. Organizasyon ve Yönetim Bilimleri Dergisi, 4(2), 211-223.

Varnali, K., \& Toker, A. (2010). Mobile marketing research: The-state-of-art. International Journal of Information Management, 30, 144-151. https://doi.org/10.1016/j.dss.2005.05.003

Vatanparast, R., \& Asil, M. (2007). Factors affecting the use of mobile advertising. International Journal of Mobile Marketing, 2(2), 21-34.

Venkatesh, V. (2000). Determinants of perceived ease of use: Integrating perceived behavioral control, computer anxiety and enjoyment into the technology acceptance model. Information Systems Research, 11, 342-365. https://doi.org/10.1287/isre.11.4.342.11872

Venkatesh, V., \& Bala, H. (2008). Technology Acceptance Model 3 and a Research Agenda on Interventions. Decision Science, 39(2), 273-315. https://doi.org/10.1111/j.1540-5915.2008.00192.x

Venkatesh, V., \& Davis, F. D. (2000). A Theoretical Extension of Technology Acceptance Model: Four Longitudinal Field Studies. Management Science, Informs, 46(2), 186-204. https://doi.org/10.1287/mnsc.46.2.186.11926

Wang, K., \& Lin, C. L. (2012). The adoption of mobile value-added services: Investigating the influence of IS quality and perceived playfulness. Managing Service Quality, 22(2), 184-208. https://doi.org/10.1108/09604521211219007

Wang, R. J. H., Malthouse, E. C., \& Krishnamurthi, L. (2015). On the Go: How Mobile Shopping Affects Customer Purchase Behavior. Journal of Retailing, 91(2), 217-234. https://doi.org/10.1016/j.jretai.2015.01.002

Wei, T. T., Marthandan, G., Chong, L. Y., Ooi, K., \& Arumugam, S. (2009). What drives Malaysian m-commerce adoption? An empirical analysis. Industrial Management and Data Systems, 370-388. https://doi.org/10.1108/02635570910939399

Wetzels, M., Odekerken-Schröder, G., \& Van Oppen, C. (2009). Using PLS path modeling for assessing hierarchical construct models: guidelines and empirical illustration. Management Information Systems Quarterly, 33(1), 177-195. https://doi.org/10.2307/20650284

Wong, K. K. K. (2013). Partial Least Squares Structural Equation Modeling (PLS-SEM) Techniques Using Smart PLS. Marketing Bulletin, 24(1), 1-32.

Wu, J., \& Wang, S. (2005). What drives mobile commerce? An empirical evaluation of the revised technology acceptance model. Information \& Management, 42(5), 719-729. https://doi.org/10.1016/j.im.2004.07.001

$\mathrm{Xu}, \mathrm{D}$. J. (2006/2007). The influence of personalization in affecting consumer attitudes toward mobile advertising in China. The Journal of Computer Information Systems, 47(2), 9-20.

Yang, H., \& Zhou, L. (2011). Extending TPB and TAM to mobile viral marketing: An exploratory study on American young consumers' mobile viral marketing attitude, intent and behavior. Journal of Targeting, Measurement and Analysis for Marketing, 19(2), 85-98. https://doi.org/10.1057/jt.2011.11

Yang, H. C. (2013). Bon Apetit for Apps: Young American Consumers' Acceptance of Mobile Applications. Journal of Computer Information Systems, 53(3), 85-95. https://doi.org/10.1080/08874417.2013.11645635

Yang, K. (2010). Determinants of US consumer mobile shopping services adoption: implications for designing mobile shopping services. Journal of Consumer Marketing, 27(3), 262-270. https://doi.org/10.1108/07363761011038338

Yang, K. (2012). Consumer Technology Traits in Determining Mobile Shopping Adoption: An Application of the Extended Theory of Planned Behavior. Journal of Retailing and Consumer Services, 19, 484-491. https://doi.org/10.1016/j.jretconser.2012.06.003

Yang, K., \& Forney, J. C. (2013). The Moderating Role of Consumer Technology Anxiety in Mobile Shopping Adoption: Differential Effects of Facilitating Conditions and Social Influences. Journal of Electronic Commerce Research, 14(4), 334-347. 
Yang, K. C. C. (2005). Exploring factors affecting the adoption of mobile commerce in Singapore. Telematics \& Informatics, 22(3), 257-277. https://doi.org/10.1016/j.tele.2004.11.003

Yousif, R. O. (2012). Factors affecting consumer attitudes towards mobile marketing. Database Marketing and Customer Strategy Management, 19(3), 147-162. https://doi.org/10.1057/dbm.2012.20

Yüce, A., Deniz A., \& Gödekmerdan, L. (2012). Tüketicilerin Mobil Pazarlama Faaliyetlerini Benimsemesi: Üniversite Öğrencileri Üzerine Bir Araştırma. Süleyman Demirel Üniversitesi, IIIBF Dergisi, 17(1), 181-198.

Zarmpou, T., Saprikis, V., Markos, A., \& Vlachopoulou, M. (2012). Modeling users' acceptance of mobile services. Electronic Commerce Research, 12, 225-248. https://doi.org/10.1007/s10660-012-9092-x

Zhang, L., Zhu, J., \& Liu, Q. (2012). A meta-analysis of mobile commerce adoption and moderating effect of culture. Computers in Human Behavior, 28, 1902-1911. https://doi.org/10.1016/j.chb.2012.05.008

\section{Copyrights}

Copyright for this article is retained by the author(s), with first publication rights granted to the journal.

This is an open-access article distributed under the terms and conditions of the Creative Commons Attribution license (http://creativecommons.org/licenses/by/4.0/). 